\title{
Indonesian Journal of Pure and Applied Chemistry
}

journal homepage: http://jurnal.untan.ac.id/index.php/IJoPAC

\section{EKSTRAKSI DAUN PELAWAN (Tristaniopsis merguensis)SEBAGAI ANTIOKSIDAN MENGGUNAKAN MICROWAVE ASSISTED EXTRACTION (MAE)}

\author{
Sito Enggiwanto ${ }^{1}$, Fusfita Istiqomah ${ }^{1}$, Kasro Daniati ${ }^{1}$, Occa Roanisca $^{1^{*}}$ and \\ Robby Gus Mahardika ${ }^{1}$ \\ ${ }^{1}$ Departement of Chemistry, Bangka Belitung University, Indonesia \\ "Corresponding author: occaroanisca@gmail.com
}

\begin{tabular}{l}
\hline ARTICLE INFO \\
Article history: \\
Received 11 July 2018 \\
Accepted 30 Desember \\
2018 \\
Available online 30 \\
December 2018 \\
Keywords: \\
Tristaniopsis \\
merguensis, Microwave \\
Assisted Extraction \\
(MAE), Antioxidant \\
\end{tabular}

\begin{abstract}
Indonesia is a country that produces a wealth of abundant biodiversity, one of which is a plant that is often cultivated the tree of Pelawan (Tristaniopsis merguensis). Pelawan trees are widely spread in Indonesia one of them found in the forests of the Bangka Belitung island. Therefore, this study aims to identify the secondary metabolites and testing antioxidants in leaf of pelawan extract by comparing methods of Microwave Assisted Extraction (MAE) with maceration method. The resistant leaf used in this study was obtained from Sempan, Bangka Belitung. The observation result shows that the use of MAE method can extract with faster time compared with maceration method. So the MAE method is more effective than the maceration method. The using of MAE method for 30 minutes obtained the highest yield percentage of $41.3 \%$ in ethanol solvent which is more effective than acetone solvent. Extraction by using 48 hour maceration yields is $28.985 \%$. While the extraction with 30 minute maceration is $13.385 \%$. Testing of antioxidant activity using Microwave Assisted Extraction (MAE) method on acetone solvent has the highest antioxidant activity than ethanol extract that is 9,501 $\mathrm{g} / \mathrm{mL}$. The use of the MAE method is more efficient in extracting the leaves of Pelawan than the maceration method when viewed from the time and antioxidant activity.
\end{abstract}

(C) 2018 IJoPAC. All rights reserved

\section{Pendahuluan}

Tristaniopsis merguensis (Griff.) Peter G. Wilson \& J. T. Waterh merupakan salah satu anggota dari famili Myrtaceae. Pohon pelawan banyak tersebar di hutan-hutan Kepulauan Bangka Belitung ${ }^{[1]}$. Tanaman ini hidup di daerah gambut dan banyak ditemukan di Indonesia salah satunya di Bangka Belitung. Pohon pelawan merupakan inang bagi madu pelawan dan jamur pelawan yang memiliki banyak manfaat dan bernilai jual tinggi. Jamur pelawan termasuk ke dalam genus Heimioporus mengandung komponen antioksidan dan asam amino esensial. Madu pelawan yang dihasilkan oleh Apis dorsata memiliki rasa pahit bercampur rasa manis dipercaya sebagai obat batuk dan obat antidiabetes ${ }^{[2]}$.

Berdasarkan penelitian sebelumnya, genus Tristaniopsis mempunyai tinggi akan kandungan senyawa fenolik dengan keunikan fenol terglikosilasi ${ }^{[3]}$. Ekstrak dengan kandungan fenolik yang tinggi sering dijadikan obat herba. Tingginya kandungan fenolik pada genus Tristaniopsis dan khasiat pada pohon pelawan Tristaniopsis merguensis yang banyak, membuat peneliti tertarik untuk 
mengungkap kandungan fitokimia pada spesies Tristaniopsis merguensis sehingga berpotensi dijadikan obat herbal.

Ekstraksi dan pemilihan pelarut yang tepat merupakan kunci dari khasiat obet herbal. Berdasarkan penelitian yang telah dilakukan hasil uji fitokimia tersebut merupakan hasil ekstraksi yang dilakukan terhadap genus Tristaniopsis dengan menggunakan metode konvensional seperti maserasi atau soxhlet. Tetapi metode ini membutuhkan waktu yang tidak sedikit. Oleh sebab itu perlu dikembangkan metode ekstraksi yang efisien dengan kadar senyawa aktif yang tinggi dan waktu yang singkat.

Beberapa metode yang digunakan dalam ekstraksi bahan alam atau tanaman seperti refluks, perkolasi, soxhlet, microwave dan maserasi. Maserasi sendiri merupakan metode ekstraksi cara dingin yang sederhana tetapi membutuhkan waktu lama. Kekurangan dari metode ekstraksi ini membutuhkan proses yang lama dalam waktu beberapa hari dan proses penyaringan yang tidak sempurna. Akibatnya zat aktif hanya mampu terekstraksi sebagian, yaitu $50 \%$ saja ${ }^{[4]}$. Oleh sebab itu perlu dilakukan pengembangan mengenai metode ekstraksi senyawa aktif dari tumbuhan khususnya pada spesies Tristaniopsis merguensis

Salah satu metode yang efisien adalah Microwave Assisted Extraction (MAE). Metode ini mengkombinasikan microwave dan pelarut ekstraksi. Keunggulan metode ini yaitu hanya membutuhkan waktu ekstraksi yang cepat, membutuhkan sedikit pelarut dan laju ekstraksi yang sangat tinggi dengan hasil yang tidak terlalu jauh dengan metode konvensional seperti maserasi dan soxhlet ${ }^{[5]}$. Penggunaan microwave ini hanya memerlukan waktu beberapa menit saja, hal ini jauh berbeda dengan metode maserasi yang membutuhkan waktu lebih dari 24 jam dan soxhlet lebih dari 20 jam ${ }^{[6]}$. Oleh sebab itu dilakukan penelitian mengenai ekstraksi daun pelawan (Tristaniopsis merguensis) dengan menggunakan metode Microwave Assisted Extraction (MAE).

\section{Material dan Metode}

\subsection{Preparasi Sampel}

Sampel penelitian ini merupakan daun Pelawan (Tristaniopsis merguensis) yang berasal dari Desa Kimak Kecamatan Pemali, Kabupaten Bangka, Povinsi Kepulauan Bangka Belitung. Selanjutnya sampel tersebut dikeringkan diudara terbuka, setelah itu digiling menjadi serbuk kering dan diayak. Serbuk dengan ukuran 100 mesh dilakukan ekstraksi dengan menggunakan metode Microwave Assisted Extraction (MAE) dan maserasi.

\subsection{Ekstraksi}

Serbuk kering daun (Tristaniopsis merguensis) diambil 1 gram dimasukkan $10 \mathrm{~mL}$ pelarut dalam tabung microwave. Pelarut yang digunakan bervariasi yaitu metanol, etanol, dan aseton. Tabung selanjutnya dimasukkan dalam Microwave Accelerated Reaction System (MARS) 6 (1200 W, $2450 \mathrm{MHz}, 80^{\circ} \mathrm{C}$ ) dengan variasi waktu 5, 10, 15, dan 30 menit. Setelah itu dipisahkan antara filtrat dengan residu menggunakan corong. Filtrat yang diperoleh dipekatkan dengan rotary evaporator vacum hingga diperoleh ekstrak pekat ${ }^{[7]}$.

Ekstraksi menggunakan maserasi dilakukan dengan melarutkan serbuk daun pelawan dengan pelarut etanol, aseton dan metanol dengan perbandingan ekstrak : pelawut 1 : 10 . Setelah itu dilakukan penyaringan dengan menggunakan corong büchner.

\subsection{Uji Antioksidan}

Pengujian aktivitas antioksidan dilakukan secara kuantitatif menggunakan metode DPPH dengan pengukuran secara spektroskopi. Ekstrak daun pelawan dibuat dalam konsentrasi 2, 5, 10, 20 dan $50 \mathrm{~g} / \mathrm{mL}$. Masing-masing konsentrasi dimasukkan dalam tabung reaksi sebanyak 1 mL dan ditambahkan larutan DPPH 100 g/mL 1 mL serta metanol p.a. 2 mL. Larutan yang 
telah ditambah DPPH dan diinkubasi selama 30 menit pada suhu $37^{\circ} \mathrm{C}$. Larutan tersebut diukur absorbansinya menggunakan spektroskopi UV-Vis pada panjang gelombang $515 \mathrm{~nm}$.

Aktivitas antioksidan ekstrak metanol, aseton, dan etanol dari daun Tristaniopsis merguensis ditentukan oleh besarnya hambatan serapan radikal DPPH melalui perhitungan persentase inhibisi serapan DPPH dengan rumus sebagai berikut:

$$
\text { \%Inhibisi }=\frac{A k-A T s}{A k} \times 100 \quad \begin{aligned}
& \mathrm{Ak}=\text { Absorban kontrol } \\
& \mathrm{As}=\text { Absorban sampel }
\end{aligned}
$$

Nilai IC $_{50}$ (inhibition concentration) didefinisikan sebagai konsentrasi sampel yang dibutuhkan untuk menghambat oksidasi sebesar 50\% atau konsentrasi sampel uji yang dibutuhkan untuk menangkap 50\% radikal DPPH. Nilai IC I0 $_{0}$ merupakan konsentrasi dimana ekstrak dapat menangkap radikal bebas sebesar $50 \%$ yang diperoleh dengan memakai persamaan regresi linier $y=a x+b{ }^{[8]}$.

\section{Hasil dan Pembahasan}

Tristaniopsis merguensis adalah spesies dari famili Myrtaceae yang belum banyak dilakukan penelitian mengenai genus Tristaniopsis merguensis namun dari spesies ini telah banyak digunakan sebagai obat tradisional untuk mengurangi kolesterol dalam tubuh, mengobati sakit mag, meningkatkan kinerja jantung dan paru-paru menyembuhkan stroke, meningkatkan daya tahan otak, anti kanker, tumor, bakteri, virus dan penyakit lainnya. Daun pelawan (Tristaniopsis merguensis) sendiri merupakan jenis pohon dengan batang berwarna merah dengan bagian kulit luar yang mengelupas ${ }^{[2]}$.

Genus Tristaniopsis banyak ditemukan di dataran rendah, biasanya ditemukan di hutan. Tristaniopsis merguensis merupakan tumbuhan dikotil dengan pohon yang berukuran besar. Bentuk daunnya Obovatus atau Oblanceolatus dengan pangkal tumpul sampai meruncing ke arah tangkai daunnya. Tangkai daun bersayap. Panjang daun antara 6-8 inchi dan lebar 1,25-2,25 inchi ${ }^{[1]}$. Bunga majemuk besar, padat, putih dengan ibu tangkai bunga di ketiak daun (Axi-laris) dan berambut. Kelopak berbentuk tabung menyatu dengan bagian lobus yang tajam. Petal 5 berlekatan, benang sari banyak, berhadapan dengan petal, 5 kelompok. Ovari tenggelam atau setengah tenggelam dengan 3 ruang. Buah kapsul dengan 3 lokus, sebagian tertutup kelopak, dan biji bersayap ${ }^{[2]}$.

Spesies Tristaniopsis merguensis merupakan salah satu spesies tumbuhan famili myrtaceae dengan pohon yang berukuran besar. Tinggi tanaman Tristaniopsis merguensis sekitar 20 meter hingga mencapai 80 meter. Kulit kayu berwarna kemerahan dan cederung mengelupas dengan bentuk pertulangan daun menyirip.

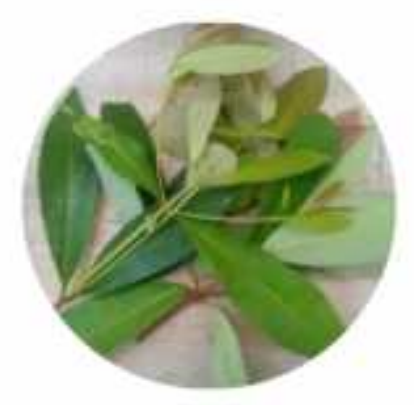

Taksonomi dari Tristaniopsis merguensis (Griff.):

$\begin{array}{ll}\text { Kingdom } & \text { : Plantae } \\ \text { Divisi } & : \text { Magnoliophyta } \\ \text { Class } & : \text { Magnoliopsida } \\ \text { Ordo } & : \text { Myrtales } \\ \text { Famili } & : \text { Myrtaceae } \\ \text { Genus } & \text { :Tristaniopsis } \\ \text { Spesies } & : \text { Tristaniopsis merguensis }\end{array}$

Gambar 1. Daun dan Taksonomi Tristaniopsis merguensis. 


\subsection{Pengaruh Waktu MAE terhadap Yield Ekstraksi}

Lamanya waktu merupakan hal yang perlu diperhatikan dalam proses ekstraksi. Optimasi ekstraksi yang pertama dilakukan adalah variasi waktu Microwave Assisted Extraction (MAE). Hasil uji variasi waktu Microwave Assisted Extraction (MAE) didapatkan hasil sebagaimana gambar 2.

\section{Pengaruh Waktu Terhadap Yield (\%)}

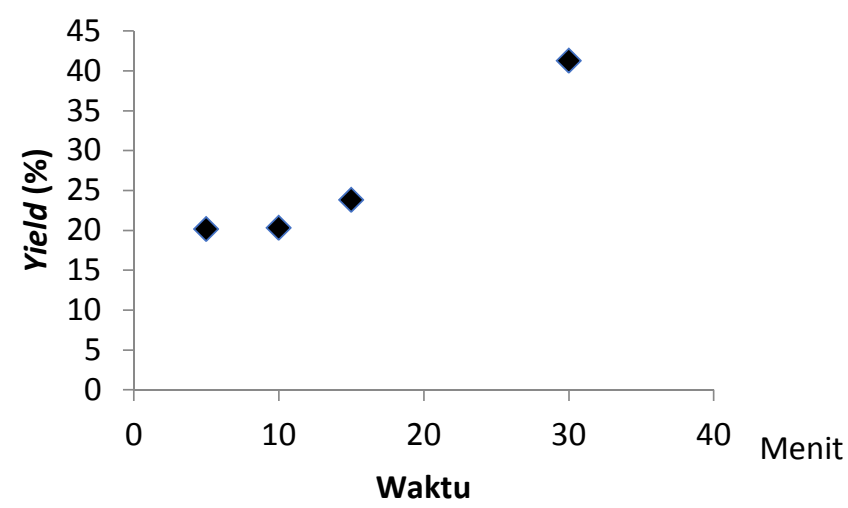

Gambar 2. Kurva Hubungan Waktu dengan Yield (\%) pada suhu $80^{\circ} \mathrm{C}$, power $1200 \mathrm{~W}$.

Dilihat dari gambar 2 menunjukkan hubungan antara waktu terhadap hasil ektraksi dimana semakin lama waktu yang dibutuhkan maka hasil ekstraksi akan semakin besar. Hal ini disebabkan karena pelarut yang berinteraksi dengan senyawa aktif semakin banyak sehingga senyawa yang terekstrakpun semakin banyak. Data pengamatan didapatkan pada suhu $80^{\circ} \mathrm{C}$ power $1200 \mathrm{~W}$ persentase yield yang paling tinggi pada waktu 30 menit yaitu sebesar 41,3\%.

\subsection{Metode Ekstraksi Terhadap Yield Ekstraksi}

Variasi metode dilakukan untuk mengetahui metode yang paling efektif dalam melakukan proses ekstraksi. Sebagaimana hasil yang didapatkan pada gambar 3.

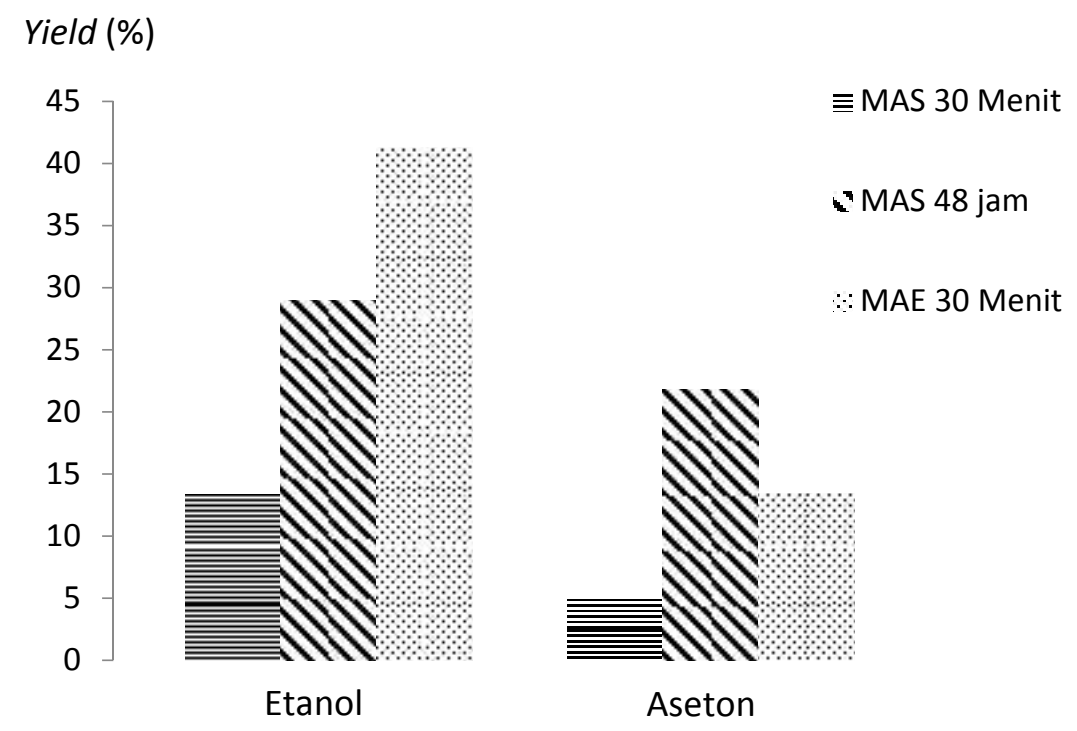

Gambar 3. Grafik Hasil Analisis Perbandingan Metode Ekstraksi Terhadap Persentase Yield (MAS : maserasi; MAE: Microwave Assisted Extraction) 
Berdasarkan diagram diatas dapat dilihat bahwa, persentase yield yang diperoleh dengan Microwave Assisted Extraction (MAE) lebih besar dibandingkan dengan metode maserasi pada waktu yang sama, baik pelarut etanol maupun aseton. Proses ektraksi berlangsung selama 30 menit yang menghasilkan persentase yield Microwave Assisted Extraction (MAE) lebih baik daripada metode maserasi. Diperoleh persentase yield yang paling besar dengan metode Microwave Assisted Extraction (MAE) pada pelarut etanol yaitu sebesar 41,3\%. Hal ini menunjukkan bahwa metode MAE lebih efektif dibandingkan maserasi jika dilihat dari segi waktu. Tetapi jika pada pelarut aseton menggunakan metode maserasi selama 48 jam menghasilkan rendemen yang lebih tinggi dibandingkan Microwave Assisted Extraction (MAE) selama 30 menit. Hal ini disebabkan waktu yang lama dari metode maserasi memperbanyak senyawa aktif yang terekstrak oleh pelarut aseton.

\subsection{Pengaruh Metode Ekstraksi dan Pelarut Terhadap Aktivitas Antioksidan}

Aktivitas antioksidan ekstrak pucuk pelawan ditentukan melalui metode DPPH. Berdasarkan gambar 4 terlihat bahwa metode ekstraksi sangat berpengaruh terhadap $\mathrm{IC}_{50}$. Hasil $\mathrm{IC}_{50}$ dengan Microwave Assisted Extraction (MAE) $(11,3117 \mu \mathrm{g} / \mathrm{mL})$ memiliki nilai yang lebih rendah dibandingkan dengan metode maserasi 48 jam $(18,2772 \mu \mathrm{g} / \mathrm{mL})$. Artinya ekstrak hasil Microwave Assisted Extraction (MAE) memiliki aktivitas antioksidan yang lebih baik dibandingkan aktivitas ekstrak maserasi. Hal ini sebanding dengan yield yang dihasilkan, pada waktu yang sama dengan Microwave Assisted Extraction (MAE) yang memiliki yield lebih bagus dibandingkan maserasi.

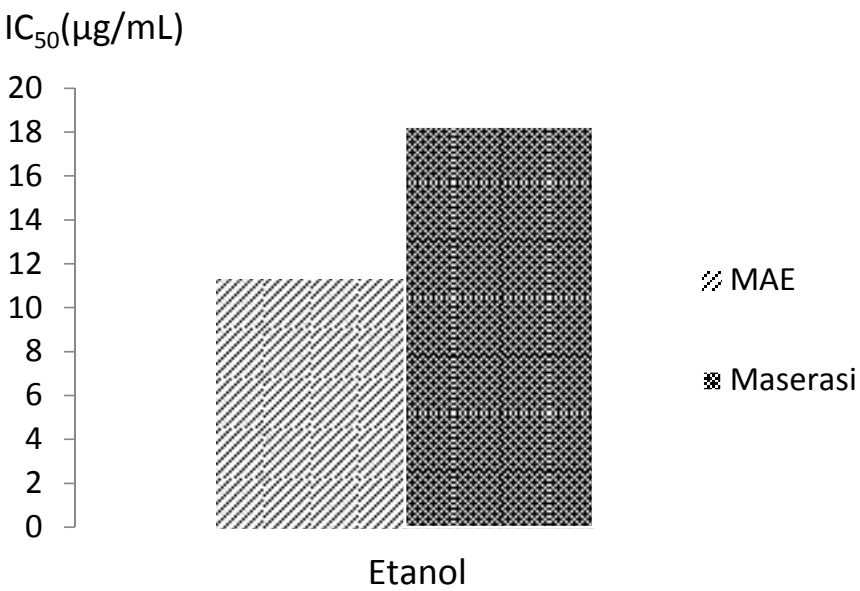

Gambar 4. Pengaruh Metode Ekstraksi Terhadap IC $C_{50}$

Berdasarkan penelitian terdahulu, kajian fitokimia dari daun pada genus Tristaniopsis mengandung $0,03 \%$ flavonoid, $0,95 \%$ saponin, dan $1,04 \%$ tanin. Senyawa aktif mayor dari genus Tristaniopsis yaitu senyawa golongan fenolik seperti flavonoid dan tanin. Senyawa fenolik yang terkandung dalam genus Tristaniopsis mempunyai keunikan fenol terglikosilasi ${ }^{[3]}$. Aktivitas antioksidan yang tinggi dari ekstrak etanol Pelawan (Tristaniopsis merguensis) ini disebabkan oleh kandungan senyawa fenolik yang tinggi seperti flavonoid, dan tanin. Kekuatan senyawa fenolik sebagai antioksidan tergantung dari beberapa faktor seperti ikatan gugus hidroksil pada cincin aromatik, posisi ikatan, posisi hidroksil pada cincin aromatik. Kemampuan dalam memberi donor hidrogen radikal mengakibatkan terbentuknya radikal fenoksil yang relatif stabil. Hidrogen radikal akan mengurangi radikal bebas yang terbentuk dalam tubuh sehingga daya tahan tubuh meningkat dan terhindar dari beberapa penyakit ${ }^{[10]}$. Oleh sebab itu ekstrak etanol daun pelawan berpotensi sebagai antioksidan yang tinggi yang kedepannya dapat menjadi prekursor obat herbal. 


\section{Kesimpulan}

Berdasarkan penelitian yang dilakukan waktu Microwave Assisted Extraction (MAE) berpengaruh terhadap yield ekstraksi daun pelawan yang dihasilkan. Semakin lama ekstraksi maka semakin besar yield ekstraksinya. Penggunaan metode MAE lebih efisien dalam mengekstrak daun pelawan dibandingkan metode maserasi jika dilihat dari segi waktu dan aktivitas antioksidan. Sedangkan pengaruh pelarut terhadap aktivitas antioksidan menunjukkan bahwa aseton memiliki aktivitas antioksidan yang sangat aktif dibandingkan pelarut etanol.

\section{Ucapan Terimakasih}

Peneliti mengucapkan terima kasih kepada Kementrian Riset, Teknologi, dan Pendidikan Tinggi Direktorat Jendral Pembelajaran dan Kemahasiswaan yang telah memberikan bantuan dana penelitian berdasarkan Surat Penugasan No 1020/B3.1/KM/2018.

\section{Daftar Pustaka}

[1] Yarli, N., 2011. Ekologi pohon pelawan (Tristaniopsis merguensis Griff.) sebgaai Inang Jamur Pelawan di Kabupaten Bangka Tengah, Bogor: Sekolah Pascasarjana institut Pertanian Bogor.

[2]. Abarini, D., 2016. Pohon pelawan (Tristaniopsis merguensis): Spesies Kunci Keberlanjutan Tanaman Keanekaragaman Hayati Namang-Bangka Belitung. Al-kauniyah Jurnal Biologi, 9: 6673.

[3]. Verotta, L, 2001. In vitro antiplasmodial activity of extracts of Tristaniopsis species and identification of the active constituents: ellagic acid and 3,4,5- trimethoxyphenyl-(6-ogalloyl)-o-betha-d-glucopyranoside. Journal Natural Product, 64: 603-607.

[4]. Dungir, S.G., Katja D.G., Kamu S.V., 2012. Aktivitas Antioksidan Ekstrak Fenolik dari Kulit Buah Manggis (G. Mangostana L.). Jurnal MIPA UNSRAT Online 1,1:11-15.

[5]. Ganzler, K., Salgo, A. \& Valko, K. 1986. Microwave extraction- a novel sample

[6]. Mandal, V., Mohan, Y., Hemalatha, S. 2007. Microwave Assisted Extraction- An Innovative and Promosing Extraction Tool For Medicinal Plant Research.Pharmaconosy Reviews, 1: 7-18.

[7]. Dahmoune, F. 2015. Optimization of microwave-assisted extraction of polyphenols from M. communis L. leaves. Food Chemistry, 166: 585-595. preparation method. Journal of Chromatography, 371: 299-306.

[8]. Lisdawati, V., \& Kardono, B.S. (2006). Aktivitas antioksidan dari berbagai fraksi ekstrak daging buah dan kulit biji mahkota dewa (Phaleria macrocarpa). Media Litbang Kesehatan, 16, 1-7.

[9]. Harborne J.B. 1987. Metode Fitokimia. Edisi Ke-2 Padmawinata K, Soediro I, penerjemahan. Bandung: Institut Teknologi Bandung. Terjemahan dari: Phytochemical methods.

[10]. Mokgope, L. B. 2006. Cowpea Seed Coats and Their Extracts : Phenolic Composition and Use as Antioxidants in Sunflower Oil. South Africa: University of Pretoria 